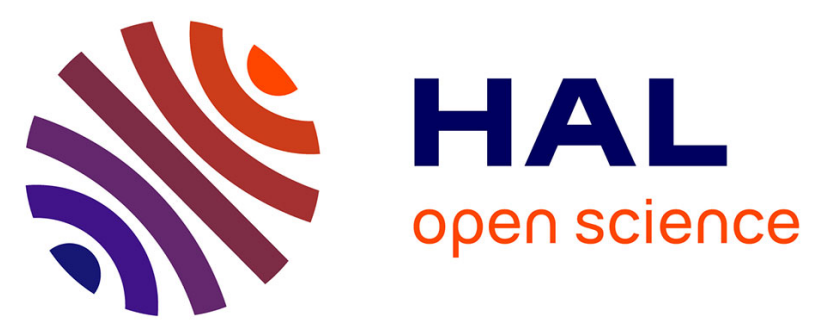

\title{
Corporate Social Responsibility Campaigns in the Digital Age: The Case of Vodafone "Red Light Application/Between Us"
}

\author{
Muge Elden, Sinem Yeygel Cakir, Ugur Bakir
}

\section{- To cite this version:}

Muge Elden, Sinem Yeygel Cakir, Ugur Bakir. Corporate Social Responsibility Campaigns in the Digital Age: The Case of Vodafone "Red Light Application/Between Us". 15th Conference on e-Business, e-Services and e-Society (I3E), Sep 2016, Swansea, United Kingdom. pp.120-127, 10.1007/978-3-31945234-0_11. hal-01702204

\section{HAL Id: hal-01702204 \\ https://hal.inria.fr/hal-01702204}

Submitted on 6 Feb 2018

HAL is a multi-disciplinary open access archive for the deposit and dissemination of scientific research documents, whether they are published or not. The documents may come from teaching and research institutions in France or abroad, or from public or private research centers.
L'archive ouverte pluridisciplinaire HAL, est destinée au dépôt et à la diffusion de documents scientifiques de niveau recherche, publiés ou non, émanant des établissements d'enseignement et de recherche français ou étrangers, des laboratoires publics ou privés. 


\title{
Corporate Social Responsibility Campaigns in the Digital Age: The Case of Vodafone "Red Light Application/Between Us"
}

\author{
Muge Elden, Sinem Yeygel Cakir, and Ugur Bakir \\ Ege University, Turkey \\ \{muge.elden.pogun, sinem.yeygel, ugur.bakir\}@ege.edu.tr
}

\begin{abstract}
The aim of this study is to reveal how new communication technologies affect corporate social responsibility campaigns by analyzing the new dimensions that corporate social responsibility campaigns acquired in the new digital era from the standpoint of the advertisers who have created these campaigns. Within the scope of this study, the social responsibility campaign undertaken by Vodafone has been investigated in its various characteristics and the study data has been obtained using the in-depth interview technique with the team of the advertisers who created the campaign. In the analysis of data obtained after interviews with the participants forming the team that created the Vodafone "Red Light Application / Between Us" social responsibility campaign it was seen that the data is grouped around three themes: These are; (1) society lifting, (2) effects of digital media and (3) "Between us" Campaign.
\end{abstract}

Keywords: Corporate social responsibility, Digital marketing, Society lifting, Vodafone, Red Light application

\section{Introduction}

In terms of a corporation creating a positive image for its target groups, in addition to having quality goods and services, efficient distribution channels, successful pricing policies and a deep-rooted history, a significant factor is the demonstration of sensitivity towards social issues. In this respect, corporate activities, which are created to increase public awareness of social responsibility in contemporary marketing, have begun to gain more significance.

Moreover, these days it is no longer sufficient for a corporation's social responsibility activities to direct attention towards a single social problem, and raise public awareness about it. Target groups expect corporations to create behavioral change or to have an effect on the public as well, and the corporations that succeed in this are those that sign up for more resourceful social responsibility activities. These kinds of social responsibility campaigns, which create participation on the behavioral level beyond that of creating social awareness and create strong changes in attitudes, cause

adfa, p. 1, 2011.

(C) Springer-Verlag Berlin Heidelberg 2011 
society to develop through the solving of social problems, raising societies to higher levels of awareness.

In addition to this, along with current developments in information communication technologies, corporations are able to involve individuals more effectively in their social responsibility campaigns and their target groups become team friends and solution partners. Digital media that has a personalized communication structure makes it possible to reach a specific audience or a specific person as a target audience with a specific content (Zeff \& Aronson, 1999: 11). At this point, information and communication technologies, specifically created for the target audience, can change the users' attitude and behaviors by using symbolic and perceptual contents for senses; and can operate a convincing communication process by directing the target audience (Canaday, 2004).

In this respect, the Vodafone Red Light Application/Between Us social responsibility campaign on violence towards women, carried out by Vodafone in 2015, is a successful example of integrating informative communication technologies with corporate social responsibility campaigns.

\section{Background}

Corporate social responsibility campaigns are applications which involve a corporation focusing attention on a social problem in order to create a benefit at the point of strategically reaching its marketing goals and serve to create a mutual benefit for both the society and the brands (Pringle \& Thompson, 1999:3). When a changing market and contemporary consumer structures are taken into consideration, corporate social responsibility becomes of increasing concern and holds strategic implications for companies across industries (Hsu, 2012: 189). As the research conducted also shows, consumers are more willing to buy goods that are specifically created for social responsibility campaigns, or associated with these campaigns, changing their buying preferences in the favor of those corporations that are more sensitive in terms of their social responsibility (Assioras et al. 2010:211). With regard to this aspect, besides making a positive contribution by showing their sensitivity towards the social environments in which they are active, thereby attributing a positive quality to their corporate image, corporate social responsibility campaigns are activities that generate additional financial benefits for the corporations.

The most important fundamental factor influencing the success of a corporate social responsibility campaign is that the campaigns' objectives are integrated into society; in other words, individuals can be made an integral part of the campaigns. At this point, the Internet and social media attract attention, as effective tools for making individuals a part of a social responsibility campaign, triggering the masses in the axis of a common goal. The pressure- removing characteristic of information communication Technologies in terms of time and geographical borders, adds strength to corporate social responsibility campaigns in the sense that they are applicable for whatever reason, by anyone, at any place and time. So much so, that this flexibility brings along with it the opportunity for corporations to act together with their shareholders through 
global networks in corporate social responsibility campaigns (Hasnaoui \& Freeman, 2010:397).

Corporations transmit their corporate social responsibility principles, philosophies and detailed information about the corporate social responsibility they implement to their target groups, through official websites and are able to shape networks that consist of businesses, civil society organizations or shareholders (Wang, 2009:63). In addition, new media environments, such as Facebook and Twitter, embody a strong effect in their own structure, which removes limitations of time and place in speed, direct interaction, and dialogue, creating participation. This characteristic allows groups, which geographically inhabit different places, to easily come together and share with each other and the network movements, activism, increase the new social movements (Schultz et al. 2013:685). In terms of a movement being initiated in this direction, Web 2.0 applications, which have a more dynamic and interactive structure and efficiency in terms creating social media in which context is produced by users themselves, have assumed a more significant role than Web 1.0 technologies, the websites of which have a static appearance (Bakker \& Hellsten, 2013:808).

In particular, the effective use of new media in corporate social responsibility campaigns has given provided a platform for the formation of a sustainable structure during the process of communication. During the corporate social responsibility campaigns carried out using social media channels, corporations carry the responsibility of spreading the themes, thoughts, and facts through the Networks in which they are also involved. Information communication technologies, in particular social media channels, present the opportunity for active participation in the creation and management of information (Hasnaoui \& Freeman, 2010:398). The magic, which is inherent in the Internet, offers advantages to corporations, in terms of spreading information in corporate social responsibility applications, adding understanding and acceleration, and presenting depth through multi channels, realizing problem management immediately on the receipt of feedback, and building a democratic structure in the communication process (Nwagbara \& Reid, 2013:410).

The structure of social media, which consists of groups that cluster around common points of interest, gives rise to applications that are carried out with common objectives and understandings; something that is regarded as normal in the corporate social responsibility campaigns realized through this channel (Hasnaoui \& Freeman, 2010:399). This paves the way for the birth of corporate social responsibility applications, which are continuously enriched contextually by the members of the network, where interactive communication within the scope of applications is achieved at the top level, and thus are added to the process by making the participation of the target group to the campaign possible, sustainable, and fast spreading, whereby numerous shareholders are able to come together from different geographical areas and with high synergy. 


\section{Campaign Overview}

Violence towards women is a widely seen social problem in Turkey, which results in many women being the victims of serious physical injury and mental abuse every year, and in some cases causing their death. Vodaphone's social responsibility campaign on violence towards women is built on an application operating in smart phones, which used by women to call for help if they are being subjected to violence. The Vodafone Red Light Application, which allows women to easily notify the police or their significant others, makes it possible to call three people with a single button, to ask for help and send an emergency message by shaking the phone. So that men do not understand what the application does, it is only women to know, it is uploaded on phones to appear like a flashlight. In addition, the application has been presented to women where men had no access; women have been informed about the red light application in areas such as ladies' rooms, lingerie tags and waxing strips which change color when heated. In addition, Vodafone, which has advertised in newspapers and areas such as ladies' rooms, where only women can visit, has videos containing the secret message of the campaign to direct them to microsites. The scope of the campaign has resulted in hundreds of thousands of women downloading the application on their phones within a short period of time, sharing it on social media through coded messages which men cannot understand. Vodafone's Between Us campaign has received the Grand Prix award at the Cannes Lions International Creativity Festival, in the Media category, the Grand CLIO award, the Golden Award, in the Integrated Campaign award at the CLIO Awards, and the silver award in the Digital category.

\section{Methodological Considerations}

In this study, corporate social responsibility campaigns, which take on new shapes within the scope of developments in the information communication technologies of the digital age, are dealt with through the campaign creators' perspective. In this study, qualitative research is preferred and a sample case is analyzed, showing how advertisers approach social responsibility campaigns in the digital age, and the new application styles in these campaigns are dealt with through the Vodafone "Red Light Application/Between Us" application, which has recently received awards on the international platform, and the perspective of the team which created it.

The research data were obtained from participants who were identified by snowball sampling using in depth interview technique. Participants working within body of Team Red that was established as an "exclusive" agency to carry out the activities of marketing communications regarding Vodafone in tandem with Young \& Rubicam (Y\&R) took active part in the process of creating "Between Us" campaign. 
Table 1. Interviewees

\begin{tabular}{ccc}
\hline Participant & Workplace & Title \\
\hline A & Y\&R Team Red Istanbul & Strategic Planner \\
B & Y\&R Team Red Istanbul & Copywriter \\
C & Y\&R Team Red Istanbul & Art Director \\
D & Y\&R Team Red Istanbul & Account Executive \\
\hline
\end{tabular}

Interviews with participants were conducted through internet. First of all, each participant was informed about the aim of the research, and then each participant answered research questions independently from one another. Since the interviews were conducted in Turkish, the research was analyzed in Turkish and translated into English after the whole analysis had been completed. Interpretative phenomenology analysis was used in the analysis of the research data. First of all, researchers read the transcriptions line by line, categorized similar data into the same groups, and developed main themes. Each theme included the opinions of the participants.

After the analysis of the data had been completed, member checking was carried out. Within the scope of member checking, research findings were emailed to the participants, and they were asked if the text reflected their views. After all of the participants gave their approval, the study took its final shape. The data obtained from the research were used in the study with the permission of Y\&R Team Red Istanbul and Vodafone Turkey.

\section{$5 \quad$ Findings}

After the data obtained from the interviews carried out with the participants involved in the team having created the social responsibility campaign of Vodafone "Red Light Application / Between Us" had been examined, it was observed that the data was collected within the scope of three themes: (1) society lifting, (2) the effects of digital media, and (3) "Between us" Campaign.

\subsection{Society Lifting}

Advertising professionals interviewed agreed upon the fact that the communication activities that brands carry out due to their social sensitivities can contribute to the solution of social problems. According to them, when right strategies, or implementations are developed, and social responsibility campaigns are not regarded as "show business", socially favorable outcomes are generated. What Strategic Planner A said about this is:

"Today, the fact that governments are unable to completely solve the problems in their countries, the impacts that companies have on the world, and many other reasons attach significant responsibilities to brands and thus, to advertisements. Today, many brands are now trying to provide solutions to issues/problems/social problems stemming from governments or themselves through their communication efforts. The con- 
tribution of the brands can be at local level like reviving a local language on the brink of extinction, or at global level like collecting donations to raise awareness for ALS disease."

Advertising professionals state that social responsibility campaigns contribute to brands at more levels than image campaigns do. Although image campaigns are important in terms of establishing emotional ties with consumers by describing the brand philosophy and belief, the expectations of consumers are changing today. What Copywriter B said is:

"While image campaigns remain at one level, communication campaigns focusing on society lifting can leave more long-lasting marks on the lives of consumers. Because image campaigns describe what the company does and its range of products etc. Thus, this means establishing a bond with consumers to some extent. However, communication studies focusing on society lifting usually find solutions to the problem of consumers. I think Turkish consumer, the problem of whom has been addressed never forgets that brand."

\subsection{The Effects of Digital Media}

According to the Advertising professionals interviewed, digital media has a power of establishing bilateral and effective communication with less people when compared to traditional media. Therefore, corporate social responsibility campaigns find more opportunities to touch the lives of the society in our era by making use of the social media. Nevertheless, benefitting both from the traditional media and corporate social responsibility campaigns may yield effective results in developing counties, especially the ones such as Turkey. What Copywriter B said about this is:

"Since the use of digital media channels is cost-effective, it is beyond that the advantages they offer are great. You can create ten times greater effect by using ten times lower budget compared to the traditional media. Nevertheless, we should not forget the great power of traditional media. Let's not forget your possibility to reach out to the whole Turkey when one of your campaign films is broadcasted during prime time."

\section{3 "Between Us" Campaign}

The team having created the "Between Us" campaign stated that the aim of their communication and media strategies was to convey the message of "Feel safe with Red Light" to women by using the channels to which only women can be exposed without mentioning the name "Vodafone", and to use the contents that women are sharing on the Internet more day by day. In this regard, the advantages that traditional media offer have not been ignored although this campaign predominantly operates through digital channels. Moreover, all the professionals in the team told that the most important feature of the campaign was the confidence it created by seeking a solution to a social problem with the promise of "confidentiality". The team members told that the insight of the "Between Us" campaign was to "reach out to women target audience through the channels only women can understand, in which men are present". 
According to Copywriter B, the general idea of the campaign stemmed from the aim to help women in the presence of violence. Because the previous campaigns run by different brands provided solutions either prior to or after violence. What was aimed with Red Light application is how to stop violence in the presence of violence. Therefore, an application that can be used by women when they are exposed to violence has been created, and was introduced to women through confidential ways, and it was ensured that they used this application when they were exposed to violence.

Art Director $\mathrm{C}$ told that the campaign succeeded due to the number of downloads, and making Vodafone innovative, reliable and recommended brand in the eyes of women. Copywriter B gave the following tangible information regarding the success of the campaign:

"A tangible criterion was how many times the application had been downloaded and activated. Application has been downloaded more than 280.000 times, and was activated more than 103.000 times In order to call for help. These results are very good for the work done. On the other hand, they are upsetting results as they show the extent of violence in Turkey. If only we could bring an end to violence, and the violence to women became something we never would come across."

\section{General Discussion}

Society lifting campaigns offering sustainable and effective solutions to social problems are highly likely to be more successful by differing from other advertisement campaigns. In this context, society lifting campaigns may contribute to the brand preference, consumption and profitability despite not in the short term. The brand health researches conducted regularly by Vodafone brand proved this. Providing bilateral communications with the target audience in corporate social responsibility campaigns, digital media makes campaigns more useful both for the brand and society. However, media planning studies should not be ignored since traditional media can easily access to a greater target audience, particularly in developing countries.

\section{$7 \quad$ Limitations and Future Research}

The basic limitations of this study are that the study approaches the subject only from advertisers' perspective, and the data obtained from depth interview technique is related only to the analyzed case. Regarding the limitations of the study, for future studies analyzing the similar cases, it would be useful to address the issue from both brands' and consumers' perspective.

\section{References}

1. Assiouras, I., Siomkos, G., Skourtis, G. \& Koniordos, M. (2010). Consumer perceptions of corporate social responsibility in the Greek mobile telecommunication industry. International Journal of Management Cases, Special Issue of CIRCLE International Conference, 13(3), 210-216. 
2. Bakker, F.G.A., \& Hellsten, I. (2013). Capturing online presence: Hyperlinks and semantic networks in activist group websites on corporate social responsibility. Journal of Business Ethics 118(4), 807-823.

3. Canaday, V.D. Persuasive Technology and Emotional Agents. Technical Report. Norfolk State University, 2004.

4. Hasnaoui, A. \& Freeman, I. (2010). Diffusion and implementation of corporate social responsibility (csr): the role of information and communication technologies (ict). Revue Management et Avenir (RMA), 39, 386 - 406.

5. Hsu, K. (2012). The advertising effects of corporate social responsibility on corporate reputation and brand equity: Evidence from the life insurance industry in Taiwan. Journal of Business Ethics, 109, 189-201. doi:10.1007/s10551-011-1118-0.

6. Nwagbara, U. \& Reid, P. (2013). Corporate social responsibility communication in the age of new media: Towards the logic of sustainability communication. Review of International Comparative Management, 14(3), 400-414.

7. Pringle H. \& Thompson, M. (1999). Brand spirit: how cause related marketing builds brands. Chichester, UK: Wiley.

8. Schultz, F., Castello, I. \& Morsing, M. (2013). The construction of corporate social responsibility in network society: A communication view. Journal of Business Ethics, 115(4), 681-692.

9. Wang, A. (2009). Perceptions of corporate social responsibility practices on mobile phone companies. International Journal of Mobile Marketing, 4(1), 62-68.

10. Zeff, R. \& Aronson, B. (1999) Advertising on the Internet. $2^{\text {nd }}$ Edition, New York: John Wiley \& Sons. 